\title{
Documentation and Phytochemical Screening of Traditional Beauty Products Used in Missenyi District of Tanzania
}

\author{
Sheila M. Maregesi*, Godeliver A. Kagashe, Fatuma Felix \\ Pharmacognosy Department, School of Pharmacy, Muhimbili University College of Health and Allied Sciences, \\ Dar es Salaam, Tanzania \\ Email: ${ }^{\text {smaregesi@hotmail.com }}$
}

Received 13 October 2014; revised 15 November 2014; accepted 4 December 2014

Academic Editor: Pierfrancesco Morganti, Mavicosmetics, Italy

Copyright (C) 2014 by authors and Scientific Research Publishing Inc.

This work is licensed under the Creative Commons Attribution International License (CC BY). http://creativecommons.org/licenses/by/4.0/

(c) (i) Open Access

\section{Abstract}

Background Information: The concept of beauty and cosmetics is as old as mankind and civilization. Raw materials for beauty products are dominated by petroleum and synthetic products. In recent years, there has been an increase of natural product-based cosmetics along with creating beauty from the inside by consumption of nutraceuticals. Tanzania traditional beauty products are still in use especially rural areas, but the documentation is lacking. Objectives: This work aimed at documenting traditional beauty products in Kagera region as an effort to avoid loss of useful information and available useful traditional findings for safe utilization in beauty products. Methodology: Information was obtained from knowledgeable people in Missenyi district by focus group discussion. Collected materials were identified in Botany and Zoology Departments at the University of Dar es Salaam followed by literature search and phytochemical screening. Results: This study afforded to record 13 plants, 4 animal products, mineral and other organic products. Most products are used for skin care (57\%) followed by hair care (22\%). Literature search supported the use of some of the products and plants subjected to qualitative analysis showed presence of phytochemicals relevant to beautification. Discussion: Some of the recorded plant and animal products are incorporated in natural based cosmetic products. Hazardous practice of using skin lightening plant products and dry cell powders was noted. Conclusion: The use of products which are already incorporated in the cosmetic products especially in countries where these products are well regulated should be promoted. Products reported for the first time require scientific studies to establish their effectiveness and safety. Since this study recorded the use of some dangerous materials, people need to be educated through media.

\footnotetext{
*Corresponding author.

How to cite this paper: Maregesi, S.M., Kagashe, G.A. and Felix, F. (2014) Documentation and Phytochemical Screening of Traditional Beauty Products Used in Missenyi District of Tanzania. Journal of Cosmetics, Dermatological Sciences and Applications, 4, 355-364. http://dx.doi.org/10.4236/jcdsa.2014.45047
} 
Keywords

Tanzania, Traditional Beauty Products, Phytochemicals

\section{Introduction}

A cosmetic product refers to any substance or preparation intended to be applied on various external parts of the human body (epidermis, hair system, nails, lips and external genital organs) or on the teeth and the mucous membranes of the oral cavity with a view of cleaning them, perfuming them, changing their appearance and/or correcting body odors and/or protecting them or keeping them in good conditions [1]. Since ancient times, raw materials for preparing these products have been derived from plants, animals and minerals [2].

Cosmetic beautification outcomes are also associated with nutritional and/medicinal effects. Hence, emergence of nutracosmetics is a class of health and beauty aid products that combine the benefits of nutracosmetical ingredients with the elegance, skin feel, and delivery systems [3]. Vitamins (A, C and E) obtained from vegetables and fruits protect cells and tissues against damaging effect of free radicals [4]. On the other hand, some ingredients from natural products are incorporated in cosmetic preparations due to their various therapeutic properties, e.g. sunscreen (skin protection effects), antiaging, moisturizing, antioxidant, antiinflammatory and antimicrobial effects, hair repair/growth stimulants, etc. [5].

The skin has a highly differentiated and complex organizational structure that is particularly vulnerable to free radical damage because of its contact with oxygen and other environmental stimuli [6]. When the skin is exposed to sunlight and other atmospheric conditions production of reactive oxygen species is stimulated. The reactive oxygen species then react with cellular DNA, proteins and fatty acids, causing oxidative damage and impairment of antioxidant system in the body. As a result, regulation pathways of skin are altered and lead to photo aging and sometimes skin cancer development [7].

The effects of aging include wrinkles, roughness, loss of skin elasticity and hyper or depigmentation marks. Herbal extracts or cosmetics containing herbal ingredients act on these areas and produce healing, softening, rejuvenating and sunscreen effects due to the antioxidant activity of phenolic compounds (tannins and flavonoids) present in most of the herbal products used for cosmetic purpose. The antioxidant activity is mainly due to their redox properties, which allow them to act as reducing agents, hydrogen donors and quenchers of singlet oxygen. In addition, they may also possess metal chelating properties [8]. Compared with synthetic cosmetic products, herbal products are mild, biodegradable and assumed to have low mammalian toxicity [8] [9].

In Tanzania, traditional beauty products have been overtaken by imported synthetic and herbal cosmetics. To a great extent, this is due to lack of documentation and research and development of these products that lead to unawareness of their existence among the young generation especially in urban areas. This situation prompts us to start recording such information from rural areas where these products are still meaningful for preserving indigenous knowledge with an anticipation of possible production of local products in more acceptable formulations and packaging in the future. Kagera region was chosen based on the fact that people of the Haya tribe are known for maintaining their culture and traditions that include the use of traditional beauty and products.

\section{Methodology}

Study site: Traditional beauty natural products were recorded in six different villages of Missenyi district in Kagera region namely; Byeju, Bulembo-Kyaka, Igayanza, Minziro, Mutukula and Ngando.

Study design: Focus group discussion with information providers being mainly those who are expert for decorating young girls during wedding ceremonies.

Data solicitation: Data was collected using semi-structured questionnaires and interviews in Kiswahili and Haya languages. Various questions about cosmetic products and their methods for preparation and use were asked to women who have traditional knowledge, about traditional beauty products used for cosmetics purposes i.e. maintaining/uplifting their appearance. The questionnaire consisted of the four parts:

1. What traditional cosmetic products do use for beatification purposes?

2. How are each of the mentioned product(s) prepared?

3. For what cosmetic/hygiene purposes do the mentioned product(s) used for? (i.e. face, hair, skin, nails, the oral tract, decoration of eyes and the maintenance of the skin health.) 
4. What are the outcomes for the mentioned product(s)? E.g. smoothness of the skin and slightly lightening.

Some of the botanical species and the insect mentioned by the participants were collected and identification done in Zoology and Botany Departments at the University of Dar es Salaam, Tanzania.

\subsection{Collection and Preparation of Plant Materials}

Plant materials for both herbaria preparation and phytochemical screening and the insect mentioned were collected from Missenyi district. Identification was done in Botany and Zoology Departments at the University of Dar es Salaam. The drying of plant materials was done in open under shade and took 7 to 10 days.

\subsection{Extraction}

Chemical reagents and solvent were all of the analytical grade solvents and reagents were purchased from Lab Equip Tanzania Ltd. (Dar es Salaam, Tanzania) and Scharlau Company (South Africa).

Dried aerial part of the plant materials were powdered and weighed ( $29 \mathrm{~g}$ of Bidens schimperi and $22 \mathrm{~g}$ of Cyphostemma adenocaule and $30 \mathrm{~g}$ of Cyphostemma maranguense). Each sample was defatted using petroleum ether followed exhaustive extraction with $80 \%$ methanol by maceration $(4 \times 600 \mathrm{ml})$ for the seven days. Extracts for each solvent were pooled together, filtered and concentrated to dryness under vacuum at $40^{\circ} \mathrm{C}$ using a Buchi RE 111 rotary evaporator from Gemini BV, The Netherland.

\subsection{Phytochemical Analysis}

Petroleum ether, methanol, and distilled water extracts of the three plants were used to determine chemical groups using the standard procedures using relevant reagents [10].

Test for tannins: About $0.5 \mathrm{~g}$ of each methanol extract was boiled in $20 \mathrm{ml}$ of water in their respective test tubes and then filtered. A few drops of $0.1 \%$ ferric chloride was added to each test tube. A brownish green or blue-black coloration indicates the presence of tannins.

Phlobatannins: An aqueous extract of each plant sample was boiled with 1\% aqueous hydrochloric acid. A deposition of a red precipitate indicates the presence of Phlobatannins.

Saponins: To $400 \mathrm{ml}$ of distilled water was added $50 \mathrm{~g}$ of powdered sample in a conical flask and boiled for 5 min. The mixture was filtered when still hot and $5 \mathrm{ml}$ of sterile distilled water added to a test tube containing equal amounts of cooled filtrate. The test tube was shaken vigorously for 30 seconds and then allowed to stand for 30 min. Formation of honey comb froth indicates the presence of saponins.

Flavonoids: $5 \mathrm{ml}$ of dilute ammonia solution was added to a portion of the aqueous filtrate of each plant extract followed by addition of concentrated $\mathrm{H}_{2} \mathrm{SO}_{4}$. Formation of yellow color indicates the presence of flavonoids.

Steroids: $2 \mathrm{ml}$ of acetic anhydride was added to $0.5 \mathrm{~g}$ of the methanol extract with $2 \mathrm{ml} \mathrm{H}_{2} \mathrm{SO}_{4}$. The change in colour from violet to blue or green indicates the presence of steroids.

Terpenoids: $5 \mathrm{ml}$ of the extract was mixed with $2 \mathrm{ml}$ of chloroform, and concentrated $\mathrm{H}_{2} \mathrm{SO}_{4}(3 \mathrm{ml})$ carefully added to form a layer (Salkowski test). A reddish brown coloration on the interface indicates the presence of terpenoids.

Sterols: To $5 \mathrm{ml}$ of the extract, equal volume of Salkowski's reagent was added. A bluish-red solution that slowly changes to violet-red, with the fluorescence showed the presence of sterols.

Essential oils: To $2 \mathrm{ml}$ of the extract, $0.1 \mathrm{ml}$ of $2 \mathrm{M}$ sodium hydroxide was added, followed by a small quantity of $2 \mathrm{M}$ hydrochloric acid and shaken. A white precipitate indicates the presence of essential oils.

Phenols: To $2 \mathrm{ml}$ of the extract, $2 \mathrm{ml}$ of Iron III chloride was added to the solution. A deep bluish-green solution indicates the presence of phenols.

Alkaloids: To $1 \mathrm{ml}$ of the extract, concentrated sulphuric acid was added followed by potassium dichromate crystals. An olive-green colour indicates the presence of alkaloids.

\section{Results}

\section{Ethno-Cosmetic Data}

This study recorded 23 products used for beauty purposes in Missenyi district. The major sources of these products were plants, animals, minerals and others. Proportions of these products are shown in Figure 1 and the applications are given in Figure 2. Details of the products are presented in Tables 1-3. 
Table 1. Plant derived cosmetic products used in Missenyi district.

\begin{tabular}{|c|c|c|c|}
\hline Botanical Name and Family Name & $\begin{array}{l}\text { Vernacular } \\
\text { Name }\end{array}$ & Parts Used and Preparation & Uses \\
\hline Abrus precatorius L. Fabaceae & & The bright seeds are strung make jewelry. & $\begin{array}{l}\text { Necklaces and hair bands espe- } \\
\text { cially by female children. }\end{array}$ \\
\hline Bidens schimperi Compositae & Luongwa & $\begin{array}{l}\text { Flowers are macerated in water, mixed } \\
\text { with papaya latex and applied on the skin. }\end{array}$ & To lighten the skin. \\
\hline Carica papaya L. Caricaceae & Omupapari & $\begin{array}{l}\text { Latex obtained from the stem and applied } \\
\text { directly on the skin three times a day. }\end{array}$ & $\begin{array}{l}\text { To lighten the } \\
\text { skin, emollient. }\end{array}$ \\
\hline Citrus limon Rutaceae & & $\begin{array}{l}\text { Fruit juice mixed with egg albumin, honey and } \\
\text { cucumber applied on the skin everyday at night. }\end{array}$ & $\begin{array}{l}\text { To smoothen facial skin, treat- } \\
\text { ment of acne. }\end{array}$ \\
\hline Cyphostemma adenocaule Vitaceae & Ibombo & Aerial parts are macerated in water and applied on skin. & To lighten the skin. \\
\hline Cyphostemma maranguense Vitaceae & & $\begin{array}{l}\text { Juice made from leaves is applied on the } \\
\text { normal skin or affected areas, every day. } \\
\text { Also can be mixed with water and boiled for } \\
\text { drinking to increase CD4 count in HIV patients. }\end{array}$ & $\begin{array}{l}\text { Emollient, } \\
\text { Skin diseases treatment: } \\
\text { eczema, wounds, bacterial } \\
\text { and fungal infection. }\end{array}$ \\
\hline Diospyros usambarensis Ebenaceae & omudawa & Root barks applied on the teeth. & $\begin{array}{l}\text { To whiten the teeth } \\
\text { and oral hygiene. }\end{array}$ \\
\hline Eucalyptus globulus Myrtaceae & Omukalitusi & $\begin{array}{l}\text { Leaves boiled with ghee, } \\
\text { and the steam is applied on the skin. }\end{array}$ & To smoothen the skin. \\
\hline Ficus thonningii Moraceae & Mtoma & $\begin{array}{l}\text { The milky latex often turning pinkish is used alone } \\
\text { or mixed with lemon juice and applied to the vagina } \\
\text { early in the morning every day. }\end{array}$ & $\begin{array}{l}\text { Create artificial } \\
\text { virginity in women. }\end{array}$ \\
\hline Lawsonia inermis L. Lythraceae & Ehina & $\begin{array}{l}\text { Leaves are grounded and suspended in water and applied on } \\
\text { hair or mixed with lemon juice and soot and applied on nails. }\end{array}$ & $\begin{array}{l}\text { To dye hair; } \\
\text { To color the nails. }\end{array}$ \\
\hline Musa paradisiaca L. Musaceae & Engemu & $\begin{array}{l}\text { Stem is cut into small pieces and boiled, the juice } \\
\text { is applied on the skin or the warm stem is rubbed on the } \\
\text { skin directly once or twice a day for three months. Banana } \\
\text { peels are cooked and the steam is directed to skin. } \\
\text { This is done once or twice every day for three months. }\end{array}$ & $\begin{array}{l}\text { To smoothen the skin; } \\
\text { To lighten the skin. }\end{array}$ \\
\hline Persea americana Mill. Lauraceae & & Fruit is mixed with the egg yolk and applied on hair. & $\begin{array}{l}\text { Moisturizer, anti-dandruff: } \\
\text { to strengthen hair and } \\
\text { prevent hair loss. }\end{array}$ \\
\hline Phytolacca dodecandra Phytolacaceae & Omuoko & $\begin{array}{l}\text { Seeds are mixed with papaya latex } \\
\text { and applied on cracked feet. }\end{array}$ & To smoothen the skin. \\
\hline Zea mays Poaceae & & $\begin{array}{c}\text { Corn silk (stigma) aqueous extract is used to } \\
\text { wash the skin while fresh ground corn silk is used } \\
\text { as body ointment especially after intense sun exposure. }\end{array}$ & To rejuvenate the skin. \\
\hline
\end{tabular}

Table 2. Animal mineral and others sources used for beauty in Missenyi district.

\begin{tabular}{|c|c|c|}
\hline Ingredients & Preparation & Use \\
\hline Bicycle tyre inner tubes & With petroleum jelly, applied on eye blows. & To decorate eyes, similar to eye liner. \\
\hline Snail slime & Slime is collected and rubbed on the cracked feet. & To treat cracked feet. \\
\hline Egg yolk & Mixed with avocado fruit and applied on hair. & To strengthen the hair. \\
\hline Honey & $\begin{array}{l}\text { Mixed with cucumber and lemon juice } \\
\text { and applied directly on the skin at bedtime. }\end{array}$ & To smoothen the skin. \\
\hline Kerosene & Applied on the nails three times a day. & To strengthen the nails. \\
\hline Clay (red clay) & With or without water, applied on face at night. & To give a special softness to skin. \\
\hline
\end{tabular}




\section{Continued}

Mercury oxide from battery (dry cells) powder Soft charcoal

Soft charcoal e.g. Zea mays stem charcoal

Sooty
With water or petroleum jelly applied on the hair. Applied on teeth. Crushed and mixed with petroleum jelly and applied on hair.

Fine powder is mixed with petroleum jelly and applied on eyes blows (eye liner).
Hair dye.

To whiten the teeth.

Hair dye.

To decorate the eyes.

Table 3. Detected Phytochemicals and relative amounts of Cyphostemma adenocaule, Cyphostemma maranguense and Bidens schimperi.

\begin{tabular}{|c|c|c|c|}
\hline Phytochemical Group & B. schimperi & C. maranguense & C. adenocaule \\
\hline Alkaloids & - & +++ & +++ \\
\hline Essential oils & + & + & + \\
\hline Flavonoids & +++ & - & ++ \\
\hline Phenols & ++ & - & ++ \\
\hline Phlobatannins & + & - & - \\
\hline Saponins & - & - & - \\
\hline Steroids & - & +++ & +++ \\
\hline Sterols & - & + & ++ \\
\hline Tannins & +++ & + & +++ \\
\hline Terpenoids & +++ & - & - \\
\hline
\end{tabular}

Key: += little; ++ = high; +++ = higher.

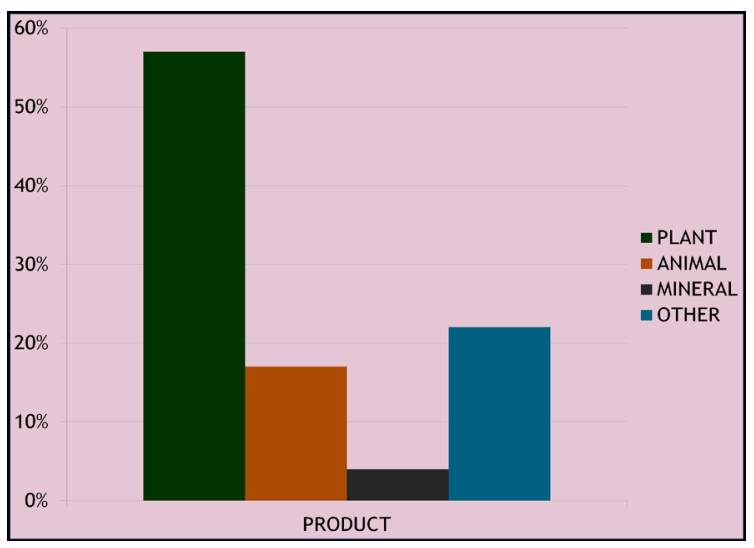

Figure 1. Proportions of beauty product sources.

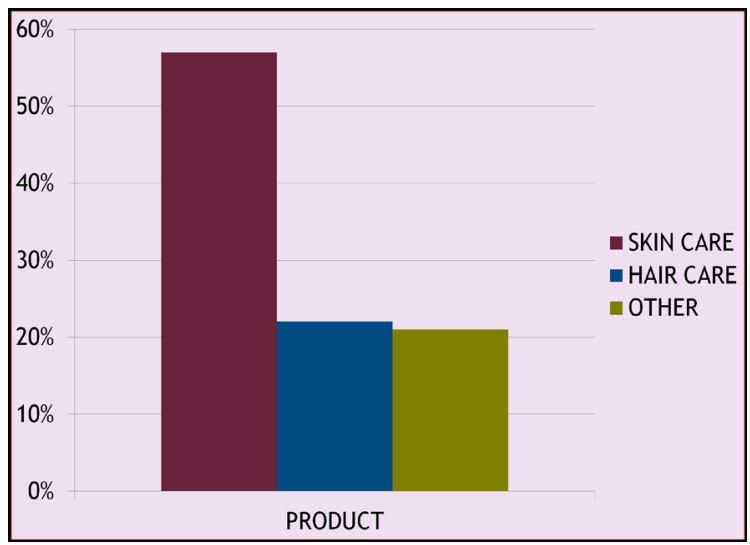

Figure 2. Proportions of product applications. 


\section{Discussion}

\subsection{General Observation}

Proportions of products for application to the skin were $(57 \%)$ and hair $(22 \%)$ this matches with people's concern on skin complexion especially the face and hair look. Regarding the skin, smooth complexion and lightening are main expected beauty outcomes. Information providers were aware of the fact that, besides topical application of cosmetic products, beauty can also result from eating certain foods (concept of nutracosmetics), e.g. banana stems and fruits. Majority of beauty products recorded in this work are supported by scientific results previous studies as described below.

\subsection{Beauty Products from Plant Sources: Previous Reports on Uses, the Phytohemical Constituents, Pharmacological and Biological Activity}

Abrus precatorius: Unlike other plant beauty products topically applied or eaten, the bright seeds of A. precatorius are strung on a thread to make necklaces and bangels which are worn to enhance good looking. In India the natives value bright coloration of $A$. precatorius seeds and use them for making necklaces and other ornaments worn by both children and adults [11].

Carica papaya latex: Latex from unripe fruits, leaves or stem of the papaya tree contains proteolytic enzymes such as papain enzymes which soften and dissolve dead skin layers and simultaneously nourish and support the creation of healthy skin. The enzymes also strengthen collagen tissue due to their ability of protecting and repairing damaged elastic collagen fibers, offering protection to the skin from developing wrinkles [12]. Externally the papaya latex is known to cause contact dermatitis [13]. Cosmetically, papain is used in some dentifrices, shampoos, and face-lifting preparations [14].

Citrus limon: Lemon juice contains citric acid and is very rich in vitamin C, which provide many health benefits for all types of the skin. The citric acid is able to exfoliate the skin, which is an important step in treating acne or pimples. It also has astringent properties, thus drying the blemish itself [15]. The juice acts as an antiaging remedy due to its antioxidant activity and can remove wrinkles and blackheads. Lemon juice is also a natural skin lightener, so it can act to reduce a pimple's redness, speeding up the healing process and cause temporary bleaching to improve the look of the skin. However, citric acid may cause skin irritation [16].

Diospyros usambarensis root bark: The antibacterial activity of 7-methyljuglone exhibited against oral pathogenic bacteria: Streptococcus sp. and Porphyromonas [17] and Diospyros species possession of naphthaquinones [18] justify the use of root bark for oral hygiene and as a teeth whitener.

Eucalyptus globulus oil: Due to its antiseptic and antifungal properties, eucalyptus oil can keep the scalp healthy by preventing microbial growth and getting rid of dandruff. It promotes hair growth, maintains strength and elasticity of hair, improves blood circulation which can help to eliminate the build-up of oil and bacteria in the hair follicles as well as revitalizing dull hair and improve hair texture by increasing the production of ceramide [19].

Ficus thonningii latex: Hayas are among those societies from different parts of the world were virginity is highly valued thus forbidden to have sex intercourse before marriage. Some people would attempt to restore virginity by applying some natural products including Ficus thonningii latex. Supporting this practice, literature search shows that, there are various herbs that can be used to overcome loose vagina or restore vaginal muscle elasticity, vaginal prolapse, vaginal dryness and discharge, and overall health of the vagina. Examples include Hamamelis virginiana and the oak plant which offer fast action in tightening vaginal walls due to its natural phenol content-tannins [20] [21]. Previous study on Ficus thonningii stem bark revealed the tannins among other chemicals and antibacterial activity [22].

Lawsonia inermis: This is used and well known worldwide as hair and nail dye whose active component, lawsone, binds to keratin. It is therefore considered semi-permanent to permanent, depending on a person's hair type. Most people will achieve a permanent color from henna, especially after the second dye. With repeated use the orange color builds up into red and then auburn [23] [24].

Musa spp: Banana fruit is used worldwide for its nutritional values and the different parts of banana plant are used to treat different diseases such as hypertension, diarrhea, peptic ulcer and cardiac diseases in human [25]. Bananas have a variety of skin care benefits. The fruit peels have antimicrobial activity against Staphylococcus and Pseudomonas [26] and high potassium content which makes them ideal for treating acne prone skin. The 
spread of bacteria in skin cells is diminished allowing pimples or blemishes to heal at a faster rate. They are known to contain antioxidants such as dopamine, ascorbic acid and flavonoids [27] [28] that provide anti-aging properties. Bananas also contain Vitamin C known to inhibit melanin production, the substance that the skin produces in response to sunlight, which darkens the skin. Banana stem juice contains manganese peroxide enzyme which causes enzymatic degradation of the skin melanin. [29] [30] Thus, skin lightening effect can be associated with anti-melanin formation and/or degradation. The antiinflamatory properties provide soothing effect for dry itchy skin preparation made from banana peels and stem. Ingested stem juice help to detoxify the body, increase skin circulation, boost collagen levels exerts antibacterial and antioxidant activity, as well as providing an overall youthful, fresh looking, smoother and glowing appearance [31].

Persea americana (Avocado oil): Supporting the use of avocado is the fact that, avocado oil present in the avocado fruit has essential nutrients like proteins, Vitamins A, D, E and B6, magnesium, copper, iron, amino acids and folic acid, all of which is extremely essential for hair growth and nourishment. Lecithin contained in the oil gives it good penetrative qualities. The avocado oil is also known to have natural sunscreen properties that can protect the hair and scalp from the damage caused by the harmful UVA and UVB rays of the sun. This oil is also effective in getting rid of dandruff [32].

Phytolacca dodecandra: It is used as a detergent, common medicinal uses include treatment of skin itching (ringworm), abortion, gonorrhea, leeches, intestinal worms, anthrax and rabies [33].

Zea mays: Chemical constituents of corn silk include; protein/amino acids, carbohydrates, flavonoids, phenols, tannins, steroids, alkaloids, terpenoids, saponins, glycosides, fat/oils fibers, vitamins and minerals (calcium, potassium, magnesium and sodium salts) [34] [35]. Corn silk is an ingredient in cosmetic face powder. Skin rejuvenation can be associated with antioxidant activity of flavonoids and tannins.

\subsection{Current Phytochemical Results}

In addition to documentation, phytochemical screening of three plants we performed revealed the presence of chemical classed that could be correlated with their use for beauty purposes as follows.

Bidens schimperi flower: Flavonoids and tannins are among other phytochemicals, shown in this study. Skin smoothening effect could be due to antioxidant activity of these compounds.

Cyphostemma adenocaule and Cyphostemma maranguense leaves: Both species showed same phytochemical profile with the presence of alkaloids, flavonoids, steroids and tannins in the similar proportions based on the colour intensity observation. However, C. maranguense contained less amounts of sterols and tannins than $C$. adenocaule. Saponins, triterpanods and phlobatannis could not be detected. Presence of steroids may be associated with their application for skin lightening since steroids have catabolic and antianabolic effect on the skin which results to the thinning of the skin, making the skin appear lighter [36]. The reported itching effect can be associated with the presence of oxalic acid which exist in form of calcium oxalate crystals known to cause dermatitis upon skin contact [37] [38].

\subsection{Beauty Products from Animal Sources: Chemical Constituents, Pharmacological and Biological Activity}

Chicken egg yolk: Using egg yolk as a natural hair conditioner or in combination with avocado pulp to nourish and strengthen hair is supported by essential nutrients present in egg yolk. These including; protein, vitamins like A, E and D, high amount of sulfur and fatty sulfur and Vitamin B12 help the hair to grow faster and possession of healthy appearance [39].

Honey: The medicinal use of honey and its incorporation in cosmetic products is well known. When applied to wounds or burns, the high sugar content prevents infections, specifically from Staphylococcus bacteria strains, as well as E. coli and Candida albicans. It is thus recommended for skin-care purposes like promoting wound healing and preventing bacterial or fungal skin infections [40].

Snail secretion (slime): Its use is well supported; the secretion is rich in proteins of high and low molecular weight hyaluronic acid and antioxidants. It has a double function when applied to human skin: (i) to stimulate the formation of collagen and elastin; (ii) dermal components that repair the damaged skin and to minimize effect of free radicals that are responsible for premature skin aging [41].

Spittlebug nymphs: Spittlebug nymphs foam contains anti-repellant chemicals: fatty acid-derived alcohols clactones and a single 1-monoacylglycerol, as well as the polyol pinitol and the polyhydroxyalkanoate, poly-3- 
hydroxybutyrate [41] [42]. Application in cosmetic products is reported for polyhydroxybutyrate a plastic-like and biodegredable material having skin oil absorbing properties incorporated in skin cleansing products, polyol pinitol having skin moisturizing properties incorporated into skin creams, sunscreens and lotions products and monoacylglycerol used as emulsifying agent [43] [44].

\subsection{Other Sources for Beauty Products}

Red clay: Clay is a natural substance with a slightly grainy texture which helps the exfoliation, while the nutrients in the clay tone, firm, and nourish the skin. It is able to draw dirt, oils and toxins, resulting in deeply cleansed and softened skin [45]. Red clay in particular is richer in iron oxide, having absorbent properties and is especially good for oily skin. It tones, stimulates, and cleanses the skin pores resulting in skin smoothening and protection against pimples [46].

Unusual products: These include dry cells and inner tube of bicycle tyre. The later contain mercury oxide which has been banned in most countries because of health concerns. Mercury is toxic to the central and peripheral nervous systems. The inhalation, ingestion or dermal exposure of any form of mercury can cause neurological and behavioural disorders, harmful effects to digestive and immune systems, lungs, skin and kidneys, and may be fatal. Symptoms include tremors, insomnia, memory loss, neuromuscular effects, headache cognitive and motor dysfunction [47].

\section{Conclusion}

This type of study was done for the first time in Tanzania. It afforded to record 13 plants, 4 animal products, minerals and organic products. Skin care products were the most reported products followed by hair care products. Some of the mentioned products are known ingredients that are incorporated in cosmetics based on natural products. These include eucalyptus oil, honey, avocado, papaya latex, egg yolk, lemon oil and corn silk. Most of these are incorporated in body creams, lotions and shampoos. Traditional beauty products reported in this study but with no scientific support require further investigation to determine their safety. Also, people should be educated on the hazardous human health effects of products like dry cells and bicycle inner tubes through mass media such as TV news paper and flares.

\section{Acknowledgements}

Our thanks are due to Ms. Rehema Amlan Nyamichwo for the facilitation of the focus group discussion and all information providers in Missenyi district for their willingness to reveal traditional natural products used for beauty purposes.

\section{References}

[1] Pieroni, A., Quave, C.L., Villanelli, M.L., Mangino, P., Sabbatini, G., Santini, L., Boccetti, T., Profili, M., Ciccioli, T., Rampa, L.G., Antonini, G., Girolamini, C., Cecchi, M. and Tomasi, M. (2004) Ethnopharmacognostic Survey on the Natural Ingredients Used in Folk Cosmetics, Cosmeceuticals and Remedies for Healing Skin Diseases in the Inland Marches, Central-Eastern Italy. Journal of Ethnopharmacology, 91, 331-344. http://dx.doi.org/10.1016/i.jep.2004.01.015

[2] Schneider, G., Gohla, S., Schreiber, J., Kaden, W., Schönrock, U., Schmidt-Lewerkühne, H., Kuschel, A., Petsitis, X., Pape, W., Ippen, H. and Diembeck, W. (2005) Skin Cosmetics: Ullmann's Encyclopedia of Industrial Chemistry. Wiley-VCH, Weinheim.

[3] Chanchal, D. and Swarnlata, S. (2008) Novel Approaches in Herbal Cosmetics. Journal of Cosmetic Dermatology, 7, 89-95. http://dx.doi.org/10.1111/j.1473-2165.2008.00369.x

[4] Mukherjee, S. and Mitra, A. (2009) Health Effects of Palm Oil. Journal of Human Ecology, 26, 197-203.

[5] Aburjai, T. and Natsheh, F.M. (2003) Plants Used in Cosmetics. Phytotherapy Research, 17, 987-1000. http://dx.doi.org/10.1002/ptr.1363

[6] Calabrese, V., Scapagnini, G., Randazzo, S.D., Randazzo, G., Catalano, C., Geraci, G. and Morganti, P. (1999) Oxidative Stress and Antioxidants at Skin Biosurface: A Novel Antioxidant from Lemon Oil Capable of Inhibiting Oxidative Damage to the Skin. Drugs under Experimental and Clinical Research, 25, 281-287.

[7] Rocha, H.M., Galindo, I., Huerta, M., Trujillo-Hernandez, B., Elizalde, A. and Cortes-Franco, R. (2002) UVB Pho- 
to-Protection with Antioxidants: Effects of Oral Therapy with d- $\alpha$-Tocopherol and Ascorbic Acid on the Minimal Erythema. Acta Dermato Venerologica, 82, 21-24. http://dx.doi.org/10.1080/000155502753600830

[8] Gulcin, I., Huyut, Z., Elmastas, M. and Aboul-Enein, H.Y. (2010) Radical Scavenging and Antioxidant Activity of Tannic Acid. Arabian Journal of Chemistry, 3, 43-53. http://dx.doi.org/10.1016/j.arabjc.2009.12.008

[9] Chanchal, D. and Swarnlata, S. (2008) Novel Approaches in Herbal Cosmetics. Journal of Cosmetic Dermatology, 7, 89-95. http://dx.doi.org/10.1111/j.1473-2165.2008.00369.x

[10] Ahumuza, T. and Kirimuhuzya, C. (2011) Qualitative (Phytochemical) Analysis and Antifungal Activity of Pentas decora (De Wild), a Plant Used Traditionally to Treat Skin Fungal Infections in Western Uganda. Research in Pharmaceutical Biotechnology, 3, 75-84.

[11] Acharya, D., Shrivastava, A., Pawar, S. and Sancheti, G. (2010) The Medicinal Value of Indian Herb Abrus precatorius Used in Herbal Medicines in India. http://www.disabled-world.com/medical/alternative/herbal/abrus-precatorius.php

[12] Silva, L.G., Garcia, O., Lopes, M.T.P. and Salas, C.E. (1997) Changes in Protein Profile during Coagulation of Latex from Carica papaya. Brazilian Journal of Medical and Biological Research, 30, 615-619. http://dx.doi.org/10.1590/S0100-879X1997000500007

[13] Aravind, G., Debjit, B., Duraivel, S. and Harish, G. (2013) Traditional and Medicinal Uses of Carica papaya. Journal of Medicinal Plants Studies, 1, 7-15.

[14] Duke, J.A. (1983) Handbook of Energy Crops. Unpublished. http://www.rain-tree.com/papaya.htm

[15] Stratford, S.J. (2013) Using Lemon Juice to Help Pimples. http://skincare.lovetoknow.com/Lemon_Juice_Help_Pimples

[16] Riggins, K. (2011) Lemon Juice and Health. http://www.livestrong.com/article/422902-lemon-juice-health

[17] Jeon, J.H., Lee, C.H., Kim, M.K. and Lee, H.S. (2009) Antibacterial Effects of Juglone and Its Derivatives against Oral Pathogens. Journal of the Korean Society for Applied Biological Chemistry, 52, 720-725. http://dx.doi.org/10.3839/jksabc.2009.119

[18] Maridass, M. (2008) Phytochemicals from Genus Diospyros (L.) and Their Biological Activities. Ethnobotanical Leaflets, 12, 231-244.

[19] Chandramita, B. (2013) Eucalyptus Oil for Hair. http://www.buzzle.com/articles/eucalyptus-oil-for-hair.html

[20] Sarina, D. and Florian, S. (2011) Investigation on the Phenolic Constituents in Hamamelis virginiana Leaves by HPLC-DAD and LC-MS/MS. Analytical and Bioanalytical Chemistry, 401, 677-688. http://dx.doi.org/10.1007/s00216-011-5111-3

[21] Jamil, M., Haq, I., Mirza, B. and Qayyum, M. (2012) Isolation of Antibacterial Compounds from Quercus dilatata L. through Bioassay Guided Fractionation. Annals of Clinical Microbiology and Antimicrobials, 11, 11 p. http://www.ann-clinmicrob.com/content/11/1/11 http://dx.doi.org/10.1186/1476-0711-11-11

[22] Usman, H., Abdulrahman, F.I. and Usman, A. (2009) Qualitative Phytochemical Screening and in Vitro Antimicrobial Effects of Methanol Stem Bark Extract of Ficus thonningii (Moraceae). African Journal of Traditional, Complementary, and Alternative Medicines, 6, 289-295.

[23] Corbett, J.F. (1998) Hair Colorants: Chemistry and Toxicology. Micelle Press, Dorset.

[24] Thompson, R.H. (1957) Naturally Occuring Quinones. Academic Press, New York.

[25] Imam, M.Z. and Akter, S. (2011) Musa paradisiacal L. and Musa sapientum L.: A Phytochemical and Pharmacological Review. Journal of Applied Pharmaceutical Science, 1, 14-20.

[26] Alisi, C.S., Nwanyanwu, C.E., Akujobi, C.O. and Ibegbulem, C.O. (2008) Inhibition of Dehydrogenase Activity in Pathogenic Bacteria Isolates by Aqueous Extracts of Musa paradisiaca (var. Sapientum). African Journal of Biotechnology, 7, 1821-1825.

[27] Yin, X.Z., Quan, J. S. and Kanazawa, T. (2008) Banana Prevents Plasma Oxidative Stress in Healthy Individuals. Plant Foods for Human Nutrition, 63, 71-76. http://dx.doi.org/10.1007/s11130-008-0072-1

[28] Vijayakumar, S., Presannakumar, G. and Vijayalakshmi, N.R. (2008) Antioxidant Activity of Banana Flavonoids. Fitoterapia, 79, 279-282. http://dx.doi.org/10.1016/j.fitote.2008.01.007

[29] Yadav, P., Singh, V.K., Yadav, M., Singh, S.K., Yadava, S. and Yadav, K.D. (2012) Purification and Characterization of Mn-Peroxidase from Musa paradisiacal (Banana) Stem Juice. Indian Journal of Biochemistry \& Biophysics, 49, 4248.

[30] Mohorcic, M., Friedrich, J., Renimel, I., Andre, P., Mandin, D. and Chaumont, J.P. (2007) Production of Melanin Bleaching Enzyme of Fungal Origin and Its Application in Cosmetics. Biotechnology and Bioprocess Engineering, 12, 200-206. 
[31] Yakinican (2014) Health Benefits of Bananas Inside and Out. http://skincareonthescars.blog.com/2014/11/01/health-benefits-of-bananas-inside-and-out/\#

[32] Mukherjee, B. (2011) Benefits of Egg Yolk on Hair. http://www.buzzle.com/articles/benefits-of-egg-yolk-on-hair.html

[33] Esser, K.B., Semagn, K. and Wolde-Yohannes, L. (2003) Medicinal Use and Social Status of the Soap Berry Endod (Phytolacca dodecandra) in Ethiopia. Journal of Ethnopharmacology, 85, 269-277. http://dx.doi.org/10.1016/S0378-8741(03)00007-2

[34] Bhaigyabati, T., Kirithika, T., Ramya, J. and Usha, K. (2011) Phytochemical Constituents and Antioxidant Activity of Various Extracts of Corn Silk (Zea mays. L). Research Journal of Pharmaceutical, Biological and Chemical Sciences, 2, 986-993.

[35] Hasanudin, K., Hashim, P. and Mustafa, S. (2012) Corn Silk (Stigma maydis) in Healthcare: A Phytochemical and Pharmacological Review. Molecules, 17, 9697-9715. http://dx.doi.org/10.3390/molecules17089697

[36] Katzung, B.G., Masters, S.B. and Trevor, A.J. (2009) Basic and Clinical Pharmacology. 11th Edition, McGraw-Hill Medical, New York.

[37] Bosch, C.H. (2004) Cyphostemma adenocaule (Steud. ex A.Rich.) Wild and R.B. Drumm. In: Grubben, G.J.H. and Denton, O.A., Eds., PROTA 2: Vegetables/Légumes, PROTA Foundation, Wageningen, 279-300.

[38] Nakata, P.A. (2012) Plant Calcium Oxalate Crystal Formation, Function, and Its Impact on Human Health. Frontiers in biology, 7, 254-266. http://dx.doi.org/10.1007/s11515-012-1224-0

[39] Mukherjee, B. (2011) Benefits of Egg Yolk on Hair. http://www.buzzle.com/articles/benefits-of-egg-yolk-on-hair.html

[40] Molan, P.C. (2009) Honey: Antimicrobial Actions and Role in Disease Management. In: Ahmad, I. and Aqil, F., Eds., New Strategies Combating Bacterial Infection, Wiley VCH, Weinheim, 229-253.

[41] Iglesias, M.C., Sanz-Rodríguez, F., Zamarrón, A., Reyes, E., Carrasco, E., González, S. and Juarranz, A. (2012) A Secretion of the Mollusc Cryptomphalus aspersa Promotes Proliferation, Migration and Survival of Keratinocytes and Dermal Fibroblasts in Vitro. International Journal of Cosmetic Science, 34, 183-89. http://dx.doi.org/10.1111/j.1468-2494.2011.00699.x

[42] Del Campo, M.L., King, J.T. and Gronquist, M.R. (2011) Defensive and Chemical Characterization of the Froth Produced by the Cercopid Aphrophora cribrata. Chemoecology, 21, 1-8.

[43] Maeda, M., Sudesh, K.K. and Iwata, T. (2008) Biodegradable Oil Absorbing Film. USPTO Application. US Patent No. 20080226580A1.

[44] Agati Group (2012) Active for Cosmetics. http://agatigroup.com/actives-for-cosmetics/

[45] Frontier Natural Products Co-Op (2013) Clay Masks. http://www.frontiercoop.com/learn/claymasks.php

[46] Carretero, M.I. and Pozo, M. (2010) Clay and Non-Clay Minerals in the Pharmaceutical and Cosmetic Industries Part II. Active Ingredients. Applied Clay Science, 47, 171-181. http://dx.doi.org/10.1016/j.clay.2009.10.016

[47] World Health Organization (2013) Mercury and Health. Fact Sheet No. 361. 
Scientific Research Publishing (SCIRP) is one of the largest Open Access journal publishers. It is currently publishing more than 200 open access, online, peer-reviewed journals covering a wide range of academic disciplines. SCIRP serves the worldwide academic communities and contributes to the progress and application of science with its publication.

Other selected journals from SCIRP are listed as below. Submit your manuscript to us via either submit@scirp.org or Online Submission Portal.
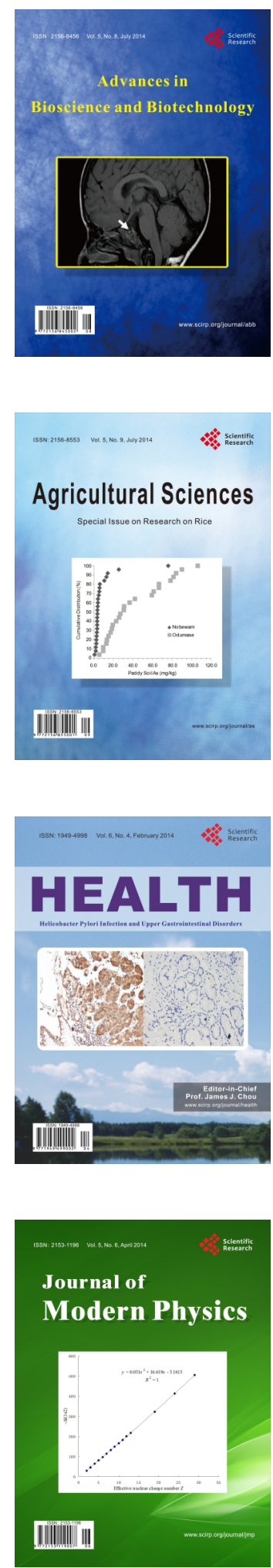
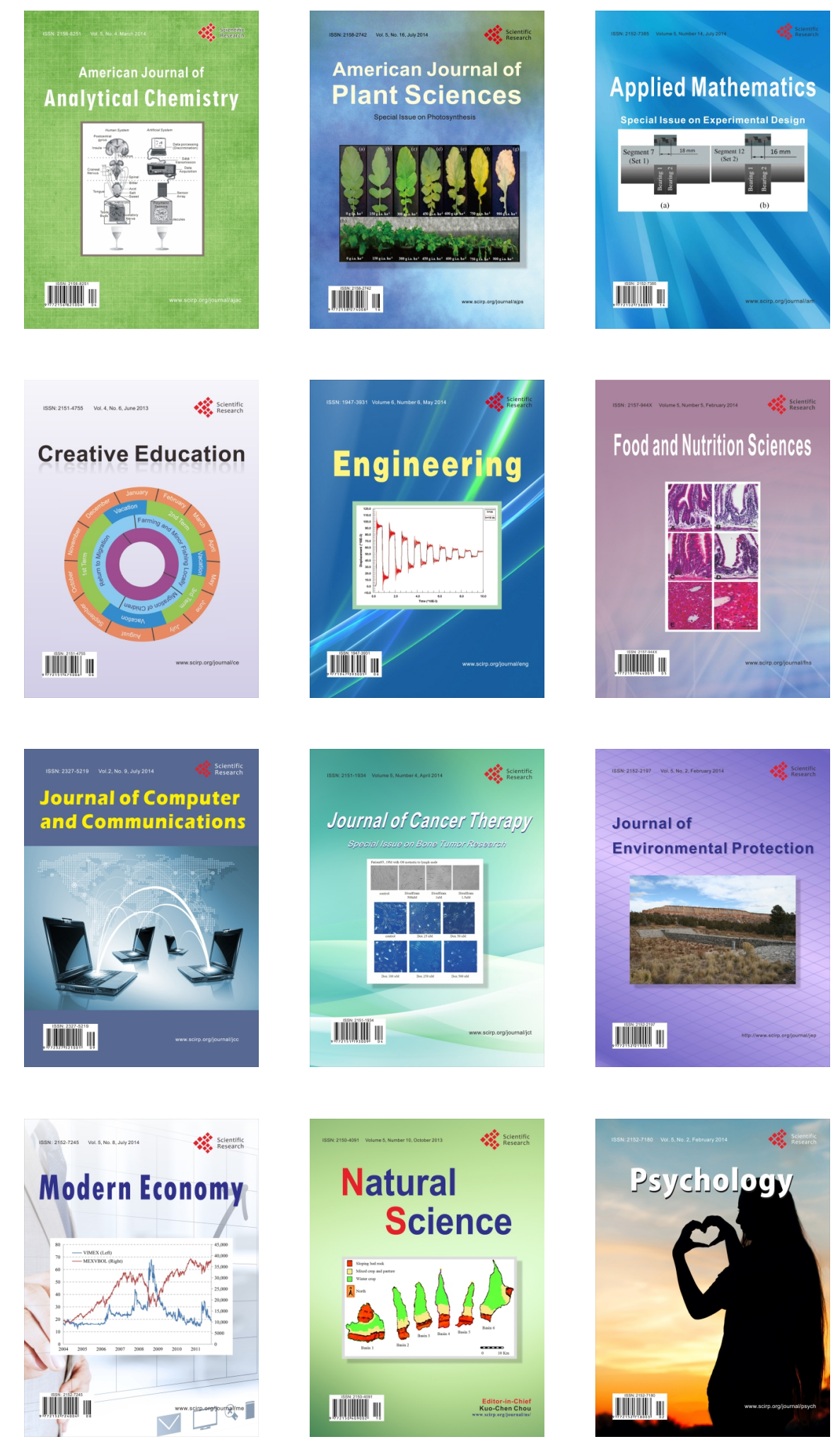